\title{
The Extradition Legislation in the Russian Federation and Germany: A Comparative Analysis
}

\author{
Kamila D. Shaibakova*1, Maria V. Talan² \\ Kazan Federal University \\ E-mail:kamila.shaibakova@gmail.com, Contact: + 79610411555
}

Received: 21st October 2017 Accepted: 16th November 2017, Published: 31st December 2017

\begin{abstract}
The article focuses on questions of legislative framework of extradition of the figutives. In the Russian Federation the norms concerning extradition are fragmented and often not ordered. So, authors of article have made the assumption that creation of the federal law on an extradition can serve systematization of knowledge of procedure and improve efficiency of its application in practice. As the proof of this theory authors have addressed experience of Germany. In Germany there is a special law on the international cooperation in criminal cases. This law is detailed and systematized and regulates questions of extradition of persons. The comparative and legal analysis of some provisions of the German law and standards of the Russian legislation are addressed in this article. The provided analysis shows that some areas aren't regulated by the existing federal legislation, such as, for example, extradition of persons for commission of military crimes. The international obligations assumed by Russia only complicate understanding of a question. Based on comparison of legislations, the conclusion has been drawn on need of development of the legislation of the Russian Federation in the field of extradition of persons. Adoption of law similar to the laws of Germany can become a step in development of the legislation and bring more effectiveness in the use of rules of law for protection of interests of the state and human rights.
\end{abstract}

Keywords: Extradition, Germany, Russian Federation, Law, Legislation, Surrender, Gesetz iiber die Internationale Rechtshilfe in Strafsachen, Act on International Cooperation in Criminal Matters.

\section{Introduction}

The process of creating the system of international security is one of the priorities for both international and national directions of actions and for national ones. The events of September 11, 2001, followed by the terrible attacks in Europe and Russia became a cornerstone in fighting terrorism and transnational organized crime. Globalization and open borders (or at least simplified procedure of crossing borders) make it easy to escape from justice. The coordination of policies and steps in combating transnational crimes are the most important acts that shall be undertaken. The extradition is an sufficient mean to do so.
The extradition is a highly complex instrument. The terminology that is being used in order to describe the process varies in both English and Russian. This can be explained by the fact that there are several similar processes that frequently misinterpret to be extradition [1]. These are the deportation, the hand over to the international courts and etc. The extradition as a complicated procedure faces numerous problems that become obstacles for an efficient and effective process. The fugitives can use the legal collisions in order to benefit themselves. The detailed and thoughtfully enacted legislation can assist in solving the problems and become a preventive instrument. Therefore, the main aim of the article is to consider whether the enacted detailed extradition legislation in Russia will be a good decision. The legislation concerning extradition in Russia is fragmentary and inconsistent. The norms and provisions are spread over the Constitution, Criminal Code, Criminal Procedure Code, bilateral and multilateral treaties.

The German Act on International Cooperation in Criminal Matters is considered to be an example of how the law like this could be. The article compares the provisions in the legal frameworks of both states and sheds light on the gaps in Russian law. The conclusion is made that the new law shall be enacted as it would make the procedure more efficient and effective and will bring more common good for the society.

\section{Methods}

The article is based on the following research question: should the federal law concerning the extradition be created in Russian Federation using the German experience? The research question is of clear normative value as it makes an attempt to illustrate how the law should be. In order to theoretically support the assumption that the federal legislature shall be enacted, we applied the Jeremy Bentham's normative theory of legislation. Pursuant to the theory, legislation shall increase "the total sum of human happiness" [2]. Thus, the theory focuses on the common good and the consequences that the legislation can bring to the society [3]. The theory will be tested in order to see whether the potential federal law will bring more common good to the society. Due to the nature of the research, the comparative research design appears to be the most appropriate. The Russian Federation and Germany were chosen as a variable because both states 
have civil law legal systems. In addition, the influence of a German Pandect system of Russian law was taken into account. Therefore, we assume that German law could be used as an example of how the similar law can be constructed. Consequently, the comparative methods will be used extensively. In order to shed a light on a background of the legislation concerning extradition in Russia, the historical method will be applied. The projective methods used as the article intends to anticipate and highlight effects of a proposed legal measure.

The academic novelty of the research defines the lack of the data. Therefore, the legislation and commentary to those legislations were used extensively.

\section{Discussion}

The Russian Federation and Germany are both states with the civil legal system that encompasses, inter alia, the written criminal legislation.

The main feature that characterizes the extradition legislation in Russia is its fragmentation. The legal provisions concerning surrender contain in the Russian Constitution [4], Criminal Code of Russia [5], Russian Code of Criminal Produced [6], bilateral agreements [7],international and regional conventions [8] and federal laws [9] that implement the treaties. The multiplicity of the sources makes it highly demanding to see the whole picture and apply the law in controversial and ordinary cases. In addition, some of the norms and provisions contradict each other or narrow the scope of others. Thus, Art. 13 Criminal Code of Russia is narrower than the constitutional provisions. Such inconsistencies cannot be logically or methodologically explained.

We made an assumption that the special federal law concerning the extradition will bring the clarity, systematic understanding of the surrender.

Germany, on the other hand, has such special law that will be considered in this article. The law, Gesetz iiber die Internationale Rechtshilfe in Strafsachen (IRG) or Act on International Cooperation in Criminal Matters [hereinafter - AICCM] [10] was adopted in 1982 and was subsequently amended. AICCM contains twelve parts. First VII parts are devoted to the description of the extradition between Germany and the Foreign States. The rest of them mainly concerns about issues considering Member States of the European Union and the European Arrest Warrant.

Interestingly, Russia previously had a special law 'About Surrender of Criminals on the Foreign States Demands'. This law, generalized provisions from the experience of bilateral agreements between Russia and other states. The law was adopted by Imperial (State) Duma on March 19, 1911. It was accepted by the Upper Chamber of the Russian Parliament and then signed by Imperator Nikolai II. The law has been in force since January 1912.

It consisted of 25 articles and de facto was a chapter of the Regulations of Criminal Proceedings. 2228
Notwithstanding, the law was not effective and was almost unnecessary at the time of the First World War. It was canceled after the events of October 1917.

Noteworthy, due to the specific nature of the extradition and its interdisciplinary character, not only national laws shall be applied. There is a variety of international treaties that shall be incorporated in the national legal systems. This includes, inter alia, the Universal Declaration of Human Rights, the International Covenant on Civil and Political Rights, the European Convention on Extradition, Geneva Conventions and others.

The word limit refrains us from the article by article comparison of the laws in both states. Therefore, we will consider separate parts in order to make a point about the paramount importance of the creation of a federal law in Russia.

We will look at the AICCM as a model law to understand which provisions might be incorporated into the Russian legislation and whether it's possible to create a new special federal law concerning the extradition.

The first part of the AICCM is devoted to the scope of application and briefly describes in which cases the law is applicable. The second part consists of provisions that might be found in the Russian Procedure Code as principles (e.g. reciprocity), prohibition to extradite on the basis of political offences and etc. However, Section 7, Part II mentions the notion of the 'military offences' and the prohibition to extradite on that basis:

"Extradition because of an offence which consists merely of a breach of military duties shall not be granted."

This provision cannot be found in Russian legislation and in bilateral agreements. However, Germany is not the only country, which refuses the requests on military offences, for example, Extradition Treaty between the USA and Argentina provides a possibility to refuse extradition for offenses under military law that are not offenses under the ordinary criminal law [12]. Moreover, Bosnia and Herzegovina's Criminal Procedure Code states that a requirement for extradition includes "that the offence on the basis of which the extradition has been requested is not a political or a military criminal offence [13]." Peru's New Code of Criminal Procedure states that an extradition shall not take place if the crime is exclusively military in nature [14]. Portugal's Law on International Judicial Cooperation in Criminal Matters provides that a request for co-operation shall also be refused where the proceedings concern any fact that constitutes a military offence [15]. The same provisions might be found in Moroccan law [16], Qatar legislation [17] and etc. There is no similar provision in Russian legislation. Art. 4 the European Convention on Extradition enshrined that offences under military law which are not offences under the ordinary criminal law are excluded from the scope of the Convention [18]. Russia ratified the Convention without the 
reservation on this regard [19]. The military offences are included in the Criminal Code of Russia under Chapter 33. However, the military offences are considered by special military courts in Russia. Thus, this is no sufficiently clear whether or not the military offences are excluded from the extradition requests. The example of military offences illustrates the inconsistency of the treaties and national legislation and prove the need of the further clarification.

Section 3(1) of the AICCM states that 'extradition shall not be granted unless the offence is an unlawful act under German law or unless mutatis mutandis the offence would also constitute an offence under German law [20].Russian legislation lacks the similar provision. Art. 462 of the Russian Criminal Procedure Code regulates extradition only when both requested and requesting States have such offence as criminally punishable in conformity with the criminal law of the Russian Federation and with the laws of the foreign state. So, there is no mentioning the possibility of mutatis mutandis application. The similar provisions might be found in the Extradition Treaty between the People's Republic of China and Russian Federation 1996. Art. 2(3) of the Treaty states that while deciding on whether the action is criminally punishable in conformity of both legislations or not, terminology and legal qualification shall not be taken into account [21]. However, in our opinion, the concept of mutatis mutandis is slightly broader. In addition, the norms can only be found in a bilateral agreement, but not in the federal legislation. This makes it highly difficult to apply as there are different standards of the extradition. The next feature that is in the comparison is the 'temporary extradition'. Russian legislation has such classification as temporary and permanent extradition. This notion can be found in Art. 465 of the Russian Criminal Code. However, there is only mentioned that if the delay of the extradition can cause expire the statute of limitation or cause damage to the investigation, a person can be extradited temporary in a case where there are assurances to be bound by the Prosecutor General's or his deputy's conditions [22]. However, in practice, there are some issues that may arise, which are excluded from the article such waiver of the return or credit of the time served by the person sought in requesting State. It might be the case that such provision might be found in a kind of 'instructions' and 'directives', which cannot be publicly accessed. The AICCM, on the other hand, greatly elaborate on this issue [23].

It is noticeable that the detailed and thoughtfully created law on extradition is a guarantee of a fair and just procedure. The law provides with the protection of not only the human rights of the fugitives but the state interests. The law assists in the efficiency and effectiveness of surrender. In addition, the law that contains the notions, terms and detailed conditions and term rises the level of legal understanding and education of the persons. It is necessary to avoid legal collision and inconsistency in law application.

Consequently, the AICCM demonstrates how the law concerning the extradition might be. We believe that this law could become a good point of departure in the creation of a bill in the Russian Federation.

\section{Summary}

Applying the theory of legislation, Jeremy Bentham argues that the principle of utility encompasses that the legislation shall bring a common good to the society. The German experience on the extradition legislation illustrates how the law could be constructed and systemized. The fragmentation of the Russian provisions concerning surrender leads to the gaps and collisions in law that could be used by the abusers. Therefore, the federal law or the detailed law on extradition is a good solution to the developed problem. The comparison of the provisions in Germany and Russia demonstrates that some parts of the extradition are not covered or covered poorly in the current legislation. The historical background of Russia illustrates that such kind of law could take place in theory. Consequently, we believe that the enactment of a law in Russia could lead to the development of the surrender.

\section{Conclusion}

Notwithstanding the summary made, the internal validity shall always be kept in mind. Despite the fact that we proved that the enactment of the legislation can bring the common good for the society and presumably good consequences, we still shall take into account the unintended side effects of any law. Presumably, the creation of a law is not a goal by itself. The rationale behind it is to make the extradition more effective and avoid the legal gaps and collusion. Therefore, we believe that the enactment of such law could become a milestone in this process.

\section{Acknowledgment}

The work is performed according to the Russian Government Program of Competitive Growth of Kazan Federal University.

\section{References}

[1] Sadoff D.A., Bringing International Fugitives to Justice: Extradition and Its Alternatives. - Cambridge University Press, 2016, pp. 667.

[2] Bentham J., Theory of Legislation. -London: Trübner \& Co, 1894, pp. 500.

[3] Kelley P.J., Theories of Legislation and Statutory Interpretation: Natural Law and the Intention of the Legislature. -Washington University Jurisprudence Review 1, no. 1, 2009, pp. 97-138.

[4] Constitution of the Russian Federation, Rossiiskaya Gazeta, December 12, 1993. 
[5] Criminal Code of the Russian Federation, No. 63FZ of June 13, 1996, available at: http://www.wipo.int/wipolex/ru/text.jsp?file_id=20246 $\underline{5}$.

[6, 22] Criminal Procedure Code of the Russian Federation, No. 174-FZ, December 18, 2001, available at:

http://www.wipo.int/edocs/lexdocs/laws/en/ru/ru065en. pdf.

[7] Treaty between the Russian Federation and Brazil, 2001; Treaty between the Russian Federation and Canada, 2000, available (in Russian) at: http://www.mid.ru/foreign_policy/international_contra cts/2_contract/-/storage-viewer/bilateral/page$\underline{184 / 46469 .}$.

[8] Federal Law 'About Ratification of the European Convention on Extradition, Additional Protocol and the Second Additional Protocol', Resolution of Plenum of Supreme Court of the Russian Federation 14 June 2012 №11.

[9, 19] Federal law № 190-FZ 'About European Extradition Convention Ratification, October 25, 1999, available at: http://pravo.gov.ru/proxy/ips/\%3Fdoc itself\%3D $\% 26$ \%26nd\%3D102062477\%26\%26page\%3D1\%26rdk\%3 D0\#I0.

$[10,11,20,23]$ Gesetz zur Umsetzung des Rahmenbeschlusses über den Europäischen Haftbefehl und die Übergabeverfahrenzwixchen den Mitgliedstaaten der Europäischen Union [Law for the Implementation of the Framework Decision on the European Arrest Warrant and the Surrender Procedures between Member States of the European Union] (in English), July 25, 2006, BGB1. I at 1721 (F.R.G.).
[12] Extradition Treaty between the Republic of Argentina and the United States of America, Buenos Aires, 10 July 1997, available (in English) at: https://www.congress.gov/treaty-document/105thcongress/18/document-text.

[13] Bosnia and Herzegovina Criminal Procedure Code, 2003, available (in English) at: http://www.legislationline.org/documents/section/crimi nal-codes/country/40.

[14] Peru, New Code of Criminal Procedure, 2004, available (in English) at: http://www.akimoo.com/structure-of-the-new-code-ofcriminal-procedure-peru/

[15] Portugal, Law on International Judicial Cooperation in Criminal Matters, 1999, available (in English) at: http://www.gddc.pt/legislacao-linguaestrangeira/english/lei144-99rev.html.

[16] Morocco, Forth Periodic report to the Committee against Torture, 5 November 2009, UN Doc., CAT/C/MAR/4, submitted 27 April 2009.

[17] Qatar, Initial report to the UN Committee against Torture, 5 October 2005, CAT/C/58/ Add.1, submitted 9 February 2005.

[18] Council of Europe, European Convention on Extradition, 13 December 1957, ETS 24.

[21] People's Republic of China and Russian Federation Extradition Treaty, 1996, available (in Russian) at: http://www.lawrussia.ru/texts/legal_185/doc185a830x7 $\underline{81 . h t m}$ 